\title{
Short Communication: Plant species richness and diversity in Karangsambung-Karangbolong National Geopark, Indonesia
}

\author{
ANGGA YUDAPUTRA ${ }^{1, \boldsymbol{v}}$, PUGUH RAHARDJO ${ }^{2}$ \\ ${ }^{1}$ Research Center of Plant Conservation and Botanic Gardens, Indonesian Institue of Sciences. Jl. Ir. H. Djuanda No.13, Paledang, Bogor 16122, West \\ Java, Indonesia. Tel.: +62-251-8311362, Fax.: +62-251-8336871, `email: angg020@ lipi.go.id \\ ${ }^{2}$ Research and Development Division for Earth Conservation and Information, Indonesian Institute of Sciences. Jl. Karangsambung Km 19, \\ Karangsambung, Kebumen 54353, West Java, Indonesia
}

Manuscript received: 11 December 2019. Revision accepted: 31 March 2020.

\begin{abstract}
Yudaputra A, Rahardjo P. 2020. Short Communication: Plant species richness and diversity in KarangsambungKarangbolong National Geopark, Indonesia. Biodiversitas 21: 1735-1742. The information on plant species richness and diversity in Karangsambung-Karangbolong National Geopark, Central Java is very limited. This study aimed: (i) to investigate plant species richness and abundance as well as floristic composition in Karangsambung-Karangbolong National Geopark; (ii) to reveal the potential uses of plant species recorded in the area. Square sampling plots were applied for nine sampling locations. Square plot of $10 \mathrm{x} 10 \mathrm{~m}$ was applied to record tree, while nested plots of $5 \times 5 \mathrm{~m}$ and $2 \times 2 \mathrm{~m}$ were applied to record sapling and understorey plants including shrubs and herbs, respectively. The highest plant species richness was found in the location with higher elevation and mountainous topography. The species abundance reaches its maximum values at low to moderate elevation. Shannon Diversity Index $(\mathrm{H})$ showed that tree and sapling have moderate diversity, whereas understorey plant has high diversity. Melastoma malabathricum, Clidemia hirta, Zingiber zerumbet, and Ageratum conyzoides are the most abundant plants in this Geopark. Most of plants recorded have potential benefit as medicinal uses.
\end{abstract}

Keywords: Abundance, diversity, Karangsambung-Karangbolong National Geopark, plant richness

\section{INTRODUCTION}

The spatial and temporal patterns of species richness, abundance and diversity remain a challenge for ecologists and biogeographers (MacArthur 1972; Lomolino 2001). The patterns of species diversity and richness along elevation gradient is more likely a little understood (Rahbek 1995, 1997; Vetaas and Grytnes 2002). Species richness is the number of different species represented in an ecological community, landscape or region. It is simply a count of species. Species abundance is the number of individuals of a species. Species diversity is defined as the combination of richness and abundance of a species that lives in certain location. Species diversity tends to decrease with increasing elevation, and the maximum species richness occurs at the intermediate or low elevation (Rahbek 1995). Species richness reaches a peak at midelevation then decreasing because species have troubles with dispersal and survival (Colwell and Hurtt 1994; Colwell and Lees 2000). Lomolino (2001) suggested that relationship between diversity and elevation depends fundamentally on the interaction of the environmental variables. In terms of understanding the pattern of diversity and richness along environmental gradients, multiple factors need to be considered to gain comprehensive understanding (Pausas and Austin 2001).

In 2018, a new Geopark located in Central Java Province was established by the Indonesian Government and named as Karangsambung-Karangbolong National Geopark. It covers area up to 2,000 ha, including Gunung Waturanda, Bukit Sipako, Gunung Paras, Gunung Brujul, and Bukit Jatibungkus. The parental geology in the Geopark was formed since Pre-tertiary era (the oldest rock over the past 60 million years) with complexity in geological conditions. Pre-tertiary rock structure is rarely found in Java Island. Its formation was composed of several types of rock, including scaly clay rock with lumps of limestone, conglomerates, sandstones, limestones, and basalt (Eocene age) (Asikin 1974). It has a unique natural phenomenon in which many types of rock are formed this formation. The theory of plate collision that took place millions of years ago makes this region as an object that stores diversity of rocks (Raharjo and Chusni 2009). Olistolit limestone was also found in this formation.

Due to the complexity of parental geology, the type of soil in Karangsambung-Karangbolong National Geopark likely varies highly. As a consequence, this variation will affect the diversity and endemicity of plants. While there have been many geological studies in the Geopark, study about the diversity of plants has been lacking. Botanical study in the area is important as the habitat of plants is highly threatened by land-use change by local people, plantation, and mining activities. The area surrounding the Geopark has various land uses, including settlement, small agricultural plantation owned by local people, forest plantation, paddy rice field, public infrastructure, marginal 
land, and shrubs (Raharjo et al. 2011). As such, it will be interesting to understand how the diversity of plants differs in those landscapes.

The combination of the complexity of parental rocks, and the diversity of land uses to make a study on the diversity of plants in Karangsambung-Karangbolong National Geopark is important to be carried out. This study trying to understand the plant species richness and abundance as well as floristic composition in Karangsambung-Karangbolong National Geopark and reveal the potential use of species recorded in the area as well.

\section{MATERIALS AND METHODS}

\section{Study period and area}

This study was conducted in KarangsambungKarangbolong National Geopark located between Kebumen and Banjarnegara District, Central Java Province, Indonesia. This study was conducted in April 2019. The sampling locations were shown in map below (Table 1).

\section{Data collection}

Several sampling plots were sampled in Karangsambung-Karangbolong National Geopark. Those sampling locations were randomly located in the study site. A square plot with two nested sub-plots was applied to record all plant species and individual numbers in all sampling locations. The plot with size $10 \times 10 \mathrm{~m}$ was used to sample the trees, while the nested plot of $5 \times 5 \mathrm{~m}$ was used to sample sapling and the nested plot of $2 \times 2 \mathrm{~m}$ was used to sample understorey plants (herbs and shrubs). Unidentified plants were brought to Bogor Botanic Garden to be rigorously characterized and identified.

Tabel 1. Sampling locations in Karangsambung-Karangbolong National Geopark, Central Java, Indonesia

\begin{tabular}{lcl}
\hline Sampling & $\begin{array}{c}\text { Elevation } \\
(\mathbf{m} \text { asl })\end{array}$ & Location \\
\hline Location 1 & 179 & Kebumen \\
Location 2 & 407 & Kebumen \\
Location 3 & 561 & Kebumen \\
Location 4 & 248 & Kebumen \\
Location 6 & 800 & Banjarnegara \\
Location 9 & 404 & Kebumen \\
Location 10 & 181 & Kebumen \\
Location 11 & 407 & Kebumen \\
Location 13 & 262 & Kebumen \\
\hline
\end{tabular}

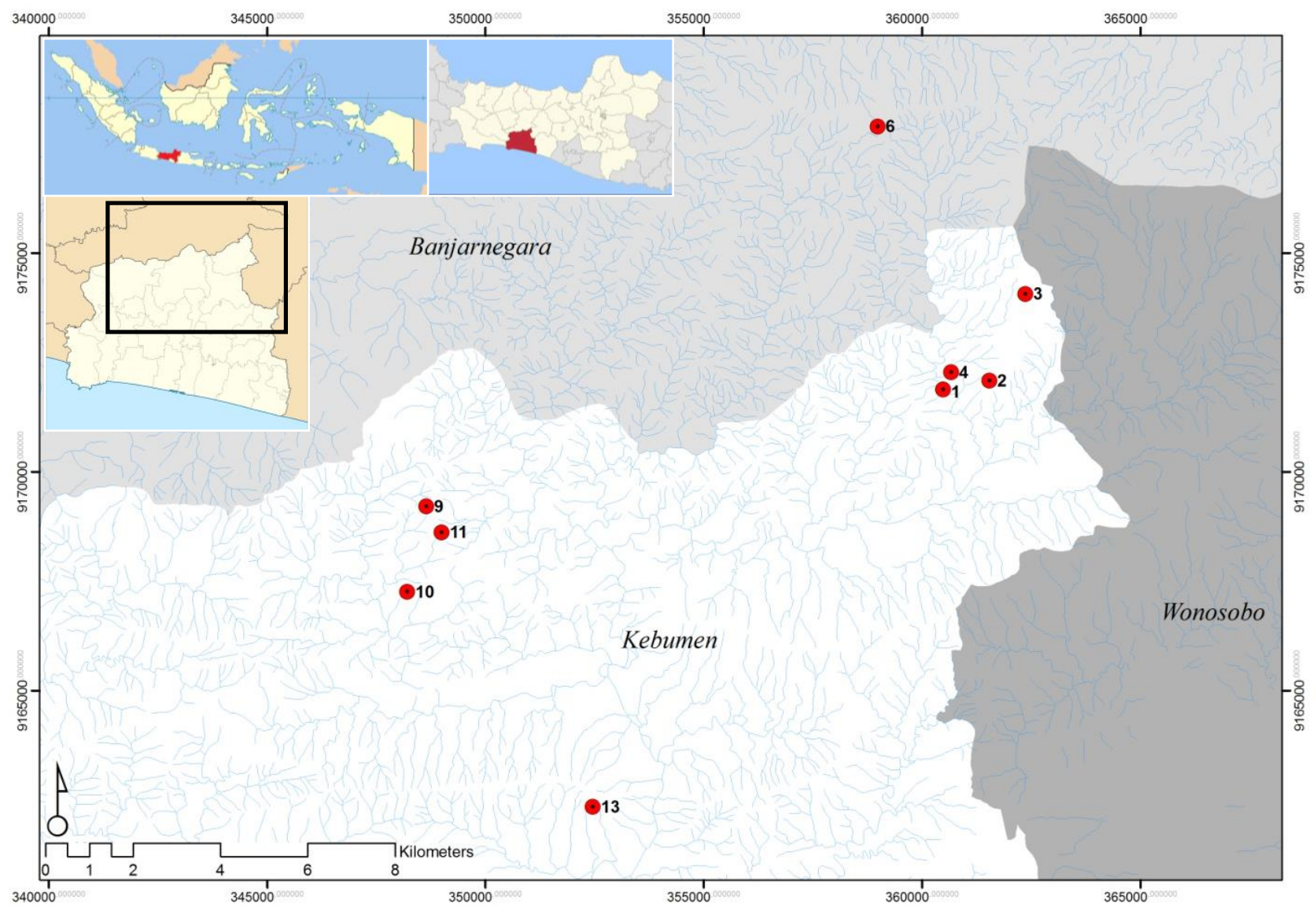

Figure 1. The study area of Karangsambung-Karangbolong National Geopark, Central Java, Indonesia 


\section{Data analysis}

The diversity of plants was measured using Shannon Diversity Index $(\mathrm{H})$. The visualization of graphic and map were processed using R statistical analysis, Microsoft Excel and Google Earth coordinate points.

The ecological importance of species in community was obtained by calculating the Important Value Index (IVI) (Curtis, 1959). This value is the sum of Relative Density (RD), Relative Frequency (RF), and Dominance Relative (DR) (Curtis, J.T. and McIntosh 1950). The formulas are as follow:

Density $(\mathrm{D})=\underline{\text { Total number of individuals }}$ Total number of quadrats studied

Relative Density $(\mathrm{RD})=$

Total number of individuals of a particular species in all quadrats x 100 Total number of individuals of all the species in all quadrats

Frequency $(\mathrm{F})=$

Number of quadrat in which the species occurred

Total number of quadrat studied

Relative Frequency $(\mathrm{RF})=$

Number of quadrats in which of species occurred x 100

Total number of all species in the quadrat

Dominance $(\mathrm{D})=$ Number of individuals Total number of individuals
Relative Dominance $(\mathrm{RD})=$

Density of individual x 100

Total number of quadrats studied

\section{RESULT AND DISCUSSION}

The highest plant richness was found in location 10 (Watukelir), followed by location 6 and location 11 (Pager Jawa), while the lowest plant richness was found in location 1 (Figure 2). Anamirta cocculus was the most abundant plant species in location 1, Xantosomas agittifoliumin in location 2, Cyclosorus opulentus in location 3, Clidemia hirta in location 4, Urena sinuata L. in location 6, Melastoma malabathricum in location 9 and 13, Pothos scandens in location 10, and Pinanga sp. in location 11 (Figure 4).

The diversity of plant species in all sampling plots were grouped based on the vegetation stages including tree, sapling, and understorey plants. Tree and sapling stage have a moderate diversity, while the understorey plant has a high diversity (Table 5). The plants recorded in all sampling plots were then categorized based on their potential uses. These included the potential for traditional medicine, food, spice, source of timber, furniture, ornamental plant, essential oil, animal fodder, source of resin, and unknown. The plants are found in Melange mostly have a potential use as traditional medicine (Figure $5)$.

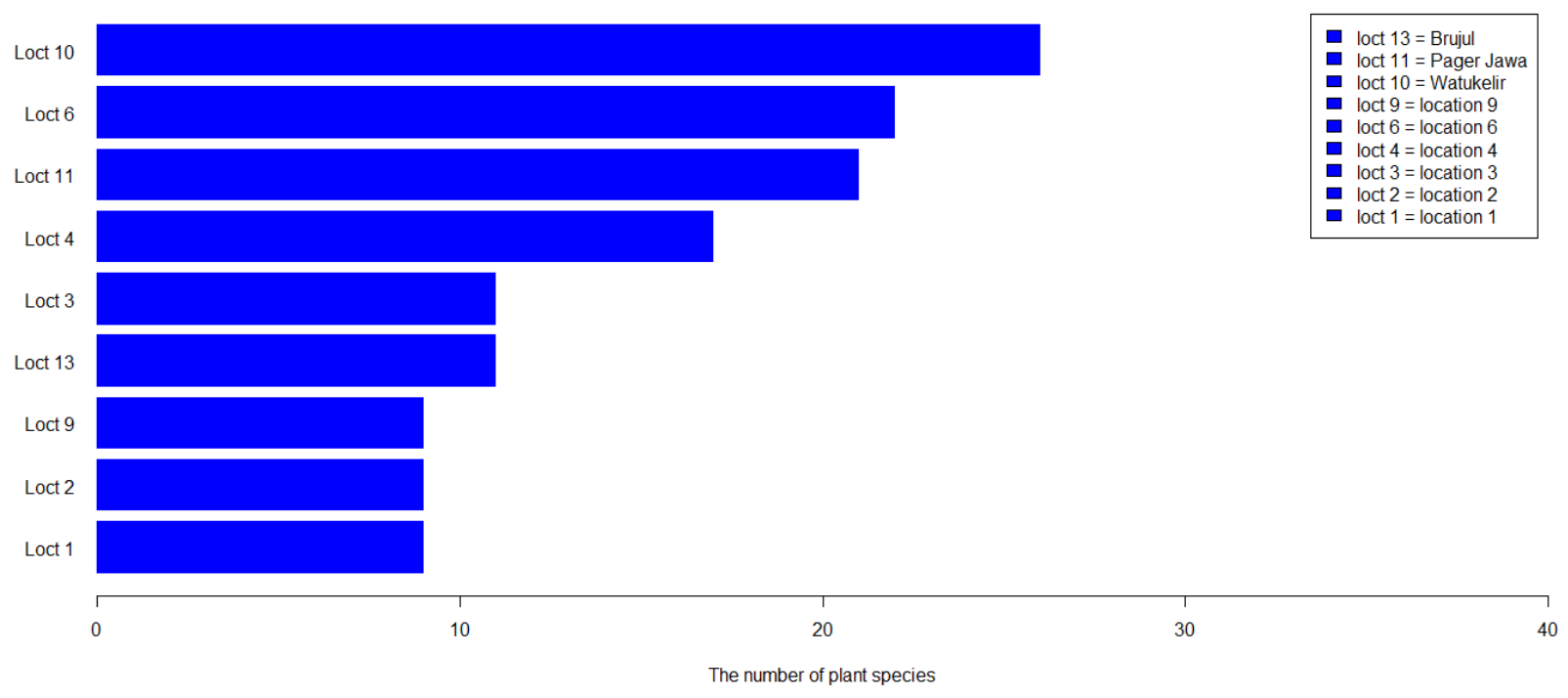

Figure 2. The plant richness in each sampling plot in Karangsambung-Karangbolong National Geopark, Central Java, Indonesia 


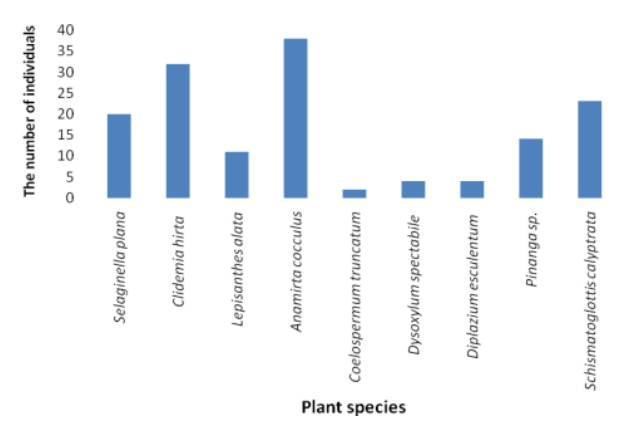

Location 1

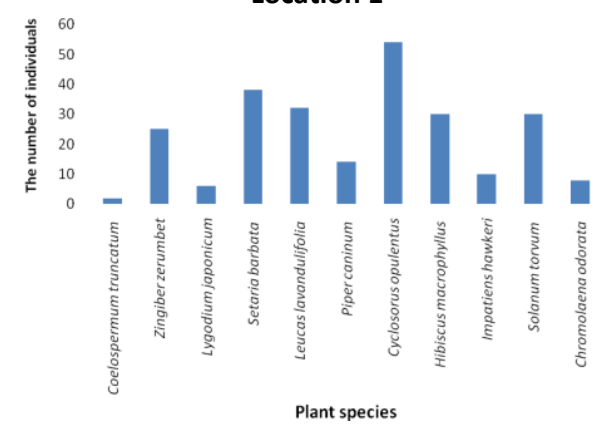

Location 3

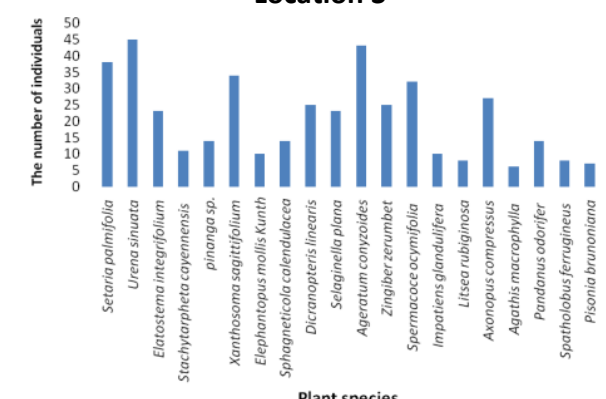

Lacation 6
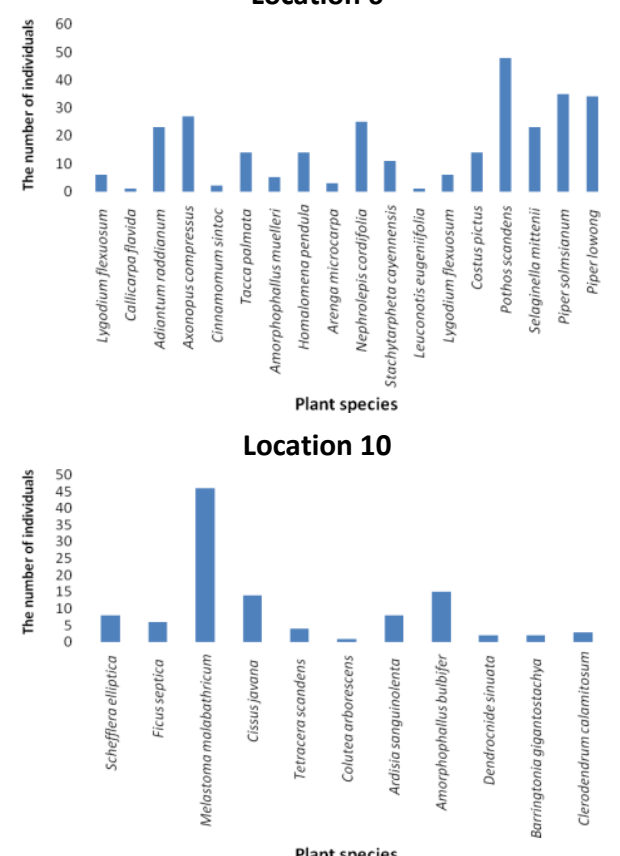

Location 13

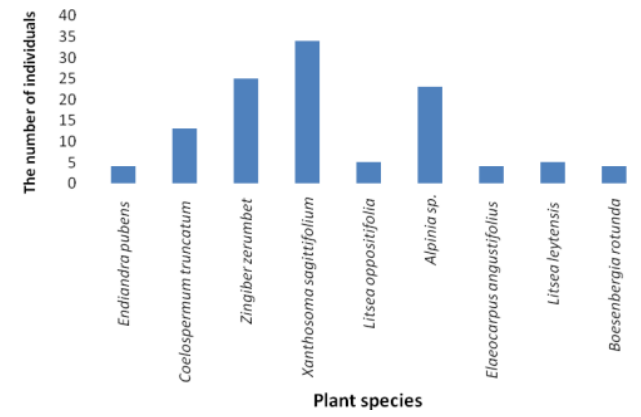

Location 2

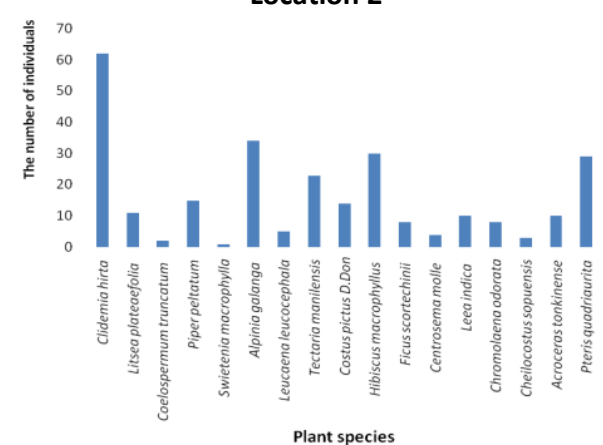

Location 4

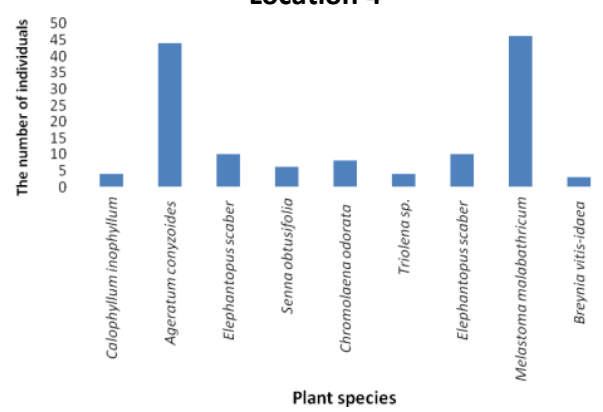

Location 9

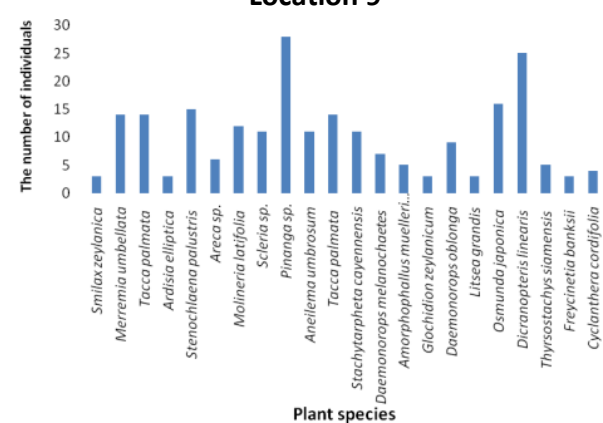

Location 11

Figure 3. The plant abundance in sampling plots of Karangsambung-Karangbolong National Geopark, Central Java, Indonesia 


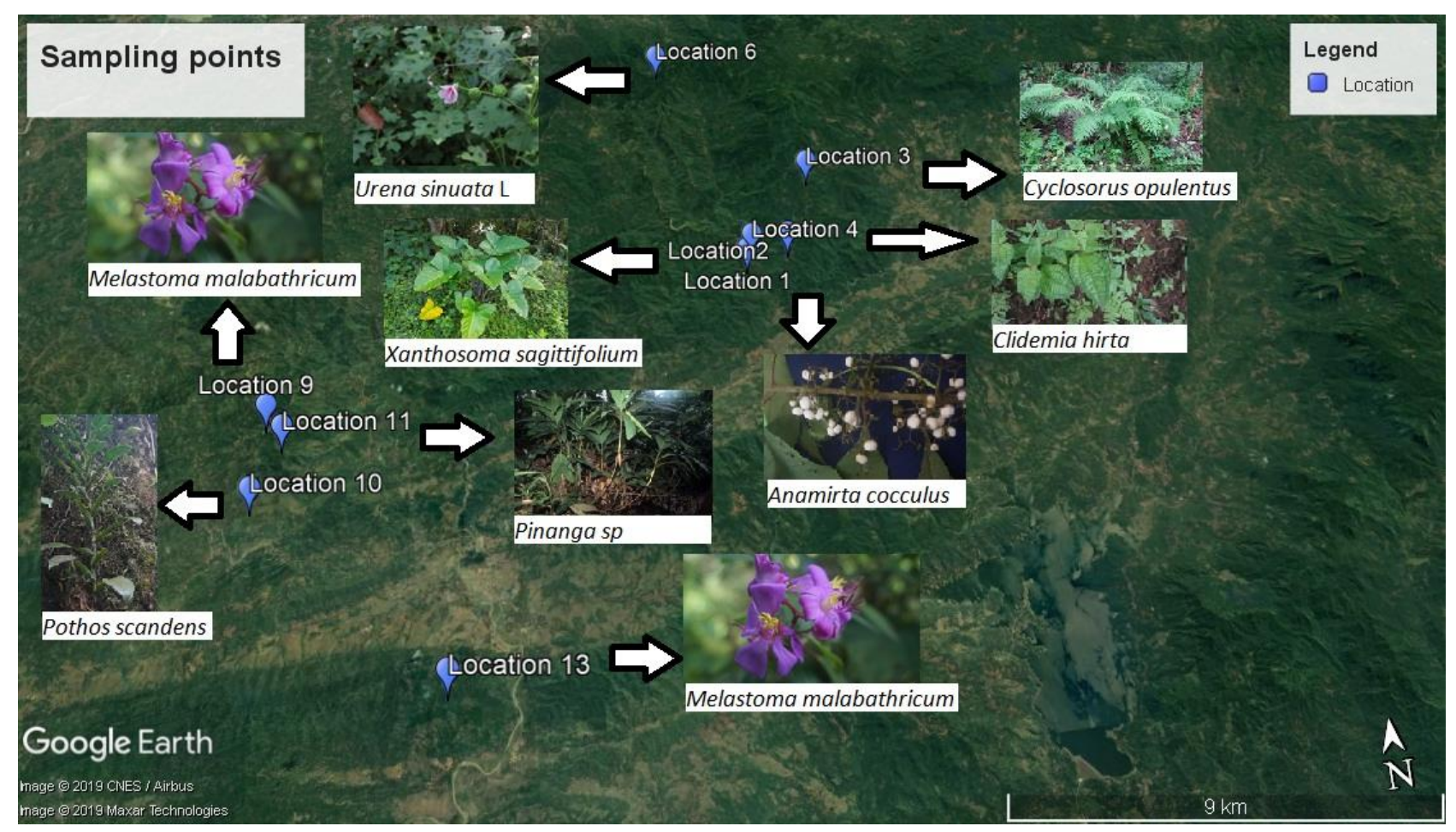

Figure 4. The most abundance of plant species that found in every sampling plot in Kebumen and Banjarnegara, Central Java, Indonesia

Table 2. The vegetation analysis of tree growth stage in all observation plots

\begin{tabular}{|c|c|c|c|c|c|c|c|c|}
\hline Plant species & $\mathbf{N}$ & D & RD & $\mathbf{F}$ & $\mathbf{R F}$ & Do & RDo & IVI \\
\hline Coelospermum truncatum (Wall.) Baill. exK.Schum. & 2 & 0.20 & 2.70 & 0.22 & 13.33 & 0.03 & 0.30 & 16.34 \\
\hline Dysoxylum spectabile (G.Forst.) Hook.f. & 4 & 0.40 & 5.41 & 0.11 & 6.67 & 0.05 & 0.60 & 12.67 \\
\hline Endiandra pubens Meisn. & 4 & 0.40 & 5.41 & 0.11 & 6.67 & 0.05 & 0.60 & 12.67 \\
\hline Litsea oppositifolia Gibbs & 5 & 0.50 & 6.76 & 0.11 & 6.67 & 0.07 & 0.75 & 14.17 \\
\hline Elaeocarpus angustifolius Blume & 4 & 0.40 & 5.41 & 0.11 & 6.67 & 0.05 & 0.60 & 12.67 \\
\hline Ficus scortechinii King & 8 & 0.80 & 10.81 & 0.11 & 6.67 & 0.11 & 1.20 & 18.68 \\
\hline Agathis pausrophylla (Lindl.) Mast. & 6 & 0.60 & 8.11 & 0.11 & 6.67 & 0.08 & 0.90 & 15.68 \\
\hline Litsea rubiginosa Boerl. & 8 & 0.80 & 10.81 & 0.11 & 6.67 & 0.11 & 1.20 & 18.68 \\
\hline Pisonia brunoniana Endl. & 7 & 0.70 & 9.46 & 0.11 & 6.67 & 0.09 & 1.05 & 17.18 \\
\hline Calophyllum inophyllum L. & 4 & 0.40 & 5.41 & 0.11 & 6.67 & 0.05 & 0.60 & 12.67 \\
\hline SterculiaguttataRoxb. ex G.Don & 5 & 0.50 & 6.76 & 0.11 & 6.67 & 0.07 & 0.75 & 14.17 \\
\hline Ardisia elliptica Thunb. & 3 & 0.30 & 4.05 & 0.11 & 6.67 & 0.04 & 0.45 & 11.17 \\
\hline Ficus septica Burm.f. & 6 & 0.60 & 8.11 & 0.11 & 6.67 & 0.08 & 0.90 & 15.68 \\
\hline Ardisia sanguinolenta Blume & 8 & 0.80 & 10.81 & 0.11 & 6.67 & 0.11 & 1.20 & 18.68 \\
\hline
\end{tabular}

Note: N: Number of species, D: Density, RD: Relative Density, F: Frequency, RF: Relative Frequency, Do: Dominance, Rdo: Relative Dominance, IVI: Important Value Index

Table 3. The vegetation analysis of sapling growth stage in all observation plots

\begin{tabular}{|c|c|c|c|c|c|c|c|c|}
\hline Plant species & $\mathbf{N}$ & D & RD & $\mathbf{F}$ & RF & Do & RDo & IVI \\
\hline Barringtonia gigantostachya Koord. \& Valeton & 2 & 0.40 & 4.08 & 0.11 & 9.09 & 0.04 & 0.45 & 13.63 \\
\hline Colutea arborescens $\mathrm{L}$. & 1 & 0.20 & 2.04 & 0.11 & 9.09 & 0.02 & 0.23 & 11.36 \\
\hline Litsea grandis (Nees) Hook.f. & 3 & 0.60 & 6.12 & 0.11 & 9.09 & 0.06 & 0.68 & 15.89 \\
\hline Glochidion zeylanicum (Gaertn.) A.Juss. & 3 & 0.60 & 6.12 & 0.11 & 9.09 & 0.06 & 0.68 & 15.89 \\
\hline Leea indica (Burm. f.) Merr. & 10 & 2.00 & 20.41 & 0.22 & 18.18 & 0.20 & 2.27 & 40.86 \\
\hline Ziziphus jujuba Mill. & 2 & 0.40 & 4.08 & 0.11 & 9.09 & 0.04 & 0.45 & 13.63 \\
\hline Leucaenaleuco cephala (Lam.) de Wit & 5 & 1.00 & 10.20 & 0.11 & 9.09 & 0.10 & 1.13 & 20.43 \\
\hline Swietenia macrophylla King & 1 & 0.20 & 2.04 & 0.11 & 9.09 & 0.02 & 0.23 & 11.36 \\
\hline Litsea plateaefolia Elmer & 11 & 2.20 & 22.45 & 0.11 & 9.09 & 0.22 & 2.49 & 34.03 \\
\hline Lepis anthesalata (Blume) Leenh. & 11 & 2.20 & 22.45 & 0.11 & 9.09 & 0.22 & 2.49 & 34.03 \\
\hline
\end{tabular}


Table 4. The vegetation analysis of understorey vegetation (shrubs and herbs) in all observation plots

\begin{tabular}{|c|c|c|c|c|c|c|c|c|}
\hline Plant species & $\mathbf{N}$ & $\mathbf{D}$ & RD & $\mathbf{F}$ & RF & Do & RDo & IVI \\
\hline Spermaco ceocymifolia Willd. exRoem. \&Schult. & 11 & 5.50 & 0.73 & 0.22 & 2.17 & 0.01 & 0.08 & 2.98 \\
\hline Senna obtusifolia (L.) H.S.Irwin \& Barneby & 6 & 3.00 & 0.40 & 0.11 & 1.09 & 0.00 & 0.04 & 1.53 \\
\hline Smilax zeylanica $\mathrm{L}$. & 3 & 1.50 & 0.20 & 0.11 & 1.09 & 0.00 & 0.02 & 1.31 \\
\hline Leuconotiseugeniifolia (Wall. ex G.Don) A.DC. & 1 & 0.50 & 0.07 & 0.11 & 1.09 & 0.00 & 0.01 & 1.16 \\
\hline Arenga microcarpa Becc. & 3 & 1.50 & 0.20 & 0.11 & 1.09 & 0.00 & 0.02 & 1.31 \\
\hline Cinnamomum sintoc Blume & 2 & 1.00 & 0.13 & 0.11 & 1.09 & 0.00 & 0.01 & 1.23 \\
\hline Callicarpa flavida Elmer & 1 & 0.50 & 0.07 & 0.11 & 1.09 & 0.00 & 0.01 & 1.16 \\
\hline Daemonorops oblonga (Reinw. ex Blume) Blume & 9 & 4.50 & 0.59 & 0.22 & 2.17 & 0.01 & 0.07 & 2.83 \\
\hline Areca sp. & 6 & 3.00 & 0.40 & 0.22 & 2.17 & 0.00 & 0.04 & 2.61 \\
\hline Aneilemaum brosum (Vahl) Kunth & 11 & 5.50 & 0.73 & 0.11 & 1.09 & 0.01 & 0.08 & 1.89 \\
\hline Stachytarpheta cayennensis (Rich.) Vahl & 11 & 5.50 & 0.73 & 0.33 & 3.26 & 0.01 & 0.08 & 4.07 \\
\hline Melastoma malabathricum $\mathrm{L}$ & 46 & 23.00 & 3.04 & 0.22 & 2.17 & 0.03 & 0.34 & 5.55 \\
\hline Tetracera scandens (L.) Merr. & 4 & 2.00 & 0.26 & 0.11 & 1.09 & 0.00 & 0.03 & 1.38 \\
\hline Dendrocnide sinuata (Blume) Chew & 2 & 1.00 & 0.13 & 0.11 & 1.09 & 0.00 & 0.01 & 1.23 \\
\hline Clerodendrum calamitosum $\mathrm{L}$. & 3 & 1.50 & 0.20 & 0.11 & 1.09 & 0.00 & 0.02 & 1.31 \\
\hline Selaginella plana (Desv. ex Poir.) Hieron. & 14 & 7.00 & 0.92 & 0.22 & 2.17 & 0.01 & 0.10 & 3.20 \\
\hline Clidemia hirta (L.) D. Don & 42 & 21.00 & 2.77 & 0.22 & 2.17 & 0.03 & 0.31 & 5.25 \\
\hline Anamirta cocculus (L.) Wight \&Arn. & 35 & 17.50 & 2.31 & 0.11 & 1.09 & 0.02 & 0.26 & 3.65 \\
\hline Diplazium esculentum (Retz.) Sw. & 4 & 2.00 & 0.26 & 0.11 & 1.09 & 0.00 & 0.03 & 1.38 \\
\hline Pinanga sp. & 14 & 7.00 & 0.92 & 0.33 & 3.26 & 0.01 & 0.10 & 4.29 \\
\hline Schismato glottiscalyptrata (Roxb.) Zoll. \&Moritzi & 23 & 11.50 & 1.52 & 0.11 & 1.09 & 0.02 & 0.17 & 2.77 \\
\hline Zingiber zerumbet (L.) Roscoe ex Sm. & 25 & 12.50 & 1.65 & 0.33 & 3.26 & 0.02 & 0.18 & 5.09 \\
\hline Xanthosomas agittifolium (L.) Schott & 34 & 17.00 & 2.24 & 0.22 & 2.17 & 0.02 & 0.25 & 4.67 \\
\hline Alpinia sp. & 23 & 11.50 & 1.52 & 0.11 & 1.09 & 0.02 & 0.17 & 2.77 \\
\hline Litsealey tensis Merr. & 6 & 3.00 & 0.40 & 0.11 & 1.09 & 0.00 & 0.04 & 1.53 \\
\hline Boesenbergia rotunda (L.) Mansf. & 4 & 2.00 & 0.26 & 0.11 & 1.09 & 0.00 & 0.03 & 1.38 \\
\hline Lygodium japonicum (Thunb.) Sw. & 23 & 11.50 & 1.52 & 0.11 & 1.09 & 0.02 & 0.17 & 2.77 \\
\hline Setaria barbata (Lam.) Kunth & 38 & 19.00 & 2.51 & 0.11 & 1.09 & 0.03 & 0.28 & 3.87 \\
\hline Leucas lavandulifolia $\mathrm{Sm}$. & 32 & 16.00 & 2.11 & 0.11 & 1.09 & 0.02 & 0.23 & 3.43 \\
\hline Piper caninum Blume & 33 & 16.50 & 2.18 & 0.22 & 2.17 & 0.02 & 0.24 & 4.59 \\
\hline Cyclosorus opulentus (Kaulf.) Nakaike & 44 & 27.00 & 3.56 & 0.11 & 1.09 & 0.04 & 0.40 & 5.05 \\
\hline Hibiscus macrophyllus Roxb. exHornem. & 30 & 15.00 & 1.98 & 0.22 & 2.17 & 0.02 & 0.22 & 4.37 \\
\hline Impatiens hawkeri W.Bull & 10 & 5.00 & 0.66 & 0.11 & 1.09 & 0.01 & 0.07 & 1.82 \\
\hline Solanum torvum $\mathrm{Sw}$. & 30 & 15.00 & 1.98 & 0.11 & 1.09 & 0.02 & 0.22 & 3.29 \\
\hline Chromolaena odorata (L.) R.M.King \& H.Rob. & 8 & 4.00 & 0.53 & 0.33 & 3.26 & 0.01 & 0.06 & 3.85 \\
\hline Piper peltatum $\mathrm{L}$. & 15 & 7.50 & 0.99 & 0.11 & 1.09 & 0.01 & 0.11 & 2.19 \\
\hline Alpinia galanga $(\mathrm{L}$.$) Willd.$ & 34 & 17.00 & 2.24 & 0.11 & 1.09 & 0.02 & 0.25 & 3.58 \\
\hline Tectaria manilensis (C. Presl) Holttum & 23 & 11.50 & 1.52 & 0.11 & 1.09 & 0.02 & 0.17 & 2.77 \\
\hline Costus pictus D.Don & 14 & 7.00 & 0.92 & 0.22 & 2.17 & 0.01 & 0.10 & 3.20 \\
\hline Centro semamolle Benth. & 4 & 2.00 & 0.26 & 0.11 & 1.09 & 0.00 & 0.03 & 1.38 \\
\hline Leea indica (Burm. f.) Merr. & 24 & 12.00 & 1.58 & 0.22 & 2.17 & 0.02 & 0.18 & 3.93 \\
\hline Acroceras tonkinense (Balansa) C.E.Hubb. ex Bor & 10 & 5.00 & 0.66 & 0.11 & 1.09 & 0.01 & 0.07 & 1.82 \\
\hline Pteris quadriaurita Retz. & 29 & 14.50 & 1.91 & 0.11 & 1.09 & 0.02 & 0.21 & 3.21 \\
\hline Setaria palmifolia (J.Koenig) Stapf & 49 & 24.50 & 3.23 & 0.11 & 1.09 & 0.03 & 0.36 & 4.68 \\
\hline $\begin{array}{l}\text { Spermacoce ocymifolia Willd. exRoem. \&Schult. } \\
\text { (synonym ; Hemidiodiaocymifolia) }\end{array}$ & 32 & 16.00 & 2.11 & 0.22 & 2.17 & 0.02 & 0.23 & 4.52 \\
\hline Urena sinuata $\mathrm{L}$. & 45 & 22.50 & 2.97 & 0.11 & 1.09 & 0.03 & 0.33 & 4.39 \\
\hline $\begin{array}{l}\text { Elatostema integrifolium var. tomentosum } \\
\text { (Hook.f.) W.T.Wang }\end{array}$ & 23 & 11.50 & 1.52 & 0.11 & 1.09 & 0.02 & 0.17 & 2.77 \\
\hline Xanthosomas agittifolium (L.) Schott & 38 & 19.00 & 2.51 & 0.22 & 2.17 & 0.03 & 0.28 & 4.96 \\
\hline Elephantopus mollis Kunth & 30 & 15.00 & 1.98 & 0.11 & 1.09 & 0.02 & 0.22 & 3.29 \\
\hline Sphagneticola calendulacea (L.) Pruski & 14 & 7.00 & 0.92 & 0.11 & 1.09 & 0.01 & 0.10 & 2.11 \\
\hline Dicranopteris linearis (Burm. f.) & 25 & 12.50 & 1.65 & 0.33 & 3.26 & 0.02 & 0.18 & 5.09 \\
\hline Selaginella Underw.plana (Desv. ex Poir.) Hieron. & 20 & 10.00 & 1.32 & 0.22 & 2.17 & 0.01 & 0.15 & 3.64 \\
\hline Ageratum conyzoides $(\mathrm{L}.) \mathrm{L}$. & 48 & 24.00 & 3.17 & 0.22 & 2.17 & 0.03 & 0.35 & 5.69 \\
\hline Axonopus compressus (Sw.) P.Beauv. & 27 & 13.50 & 1.78 & 0.22 & 2.17 & 0.02 & 0.20 & 4.15 \\
\hline Pandanus odorifer (Forssk.) Kuntze & 14 & 7.00 & 0.92 & 0.11 & 1.09 & 0.01 & 0.10 & 2.11 \\
\hline Spatholobus ferrugineus (Zoll. \& Moritzi) Benth. & 8 & 4.00 & 0.53 & 0.11 & 1.09 & 0.01 & 0.06 & 1.67 \\
\hline Elephantopus scaber L. & 10 & 5.00 & 0.66 & 0.11 & 1.09 & 0.01 & 0.07 & 1.82 \\
\hline Mikania micrantha Kunth & 7 & 3.50 & 0.46 & 0.11 & 1.09 & 0.00 & 0.05 & 1.60 \\
\hline Triolena sp. & 4 & 2.00 & 0.26 & 0.11 & 1.09 & 0.00 & 0.03 & 1.38 \\
\hline Breyniavitis-idaea (Burm.f.) C.E.C.Fisch. & 3 & 1.50 & 0.20 & 0.11 & 1.09 & 0.00 & 0.02 & 1.31 \\
\hline Osmunda japonica Thunb. & 16 & 8.00 & 1.06 & 0.22 & 2.17 & 0.01 & 0.12 & 3.35 \\
\hline
\end{tabular}




\begin{tabular}{lllllllll}
\hline Lomariopsis marginata (Schrad.) Kuhn & 6 & 3.00 & 0.40 & 0.11 & 1.09 & 0.00 & 0.04 & 1.53 \\
Piper caninum Blume & 14 & 7.00 & 0.92 & 0.22 & 2.17 & 0.01 & 0.10 & 3.20 \\
Lygodium flexuosum (L.) Sw. & 6 & 3.00 & 0.40 & 0.11 & 1.09 & 0.00 & 0.04 & 1.53 \\
Adiantum raddianum C. Presl & 23 & 11.50 & 1.52 & 0.11 & 1.09 & 0.02 & 0.17 & 2.77 \\
Tacca palmata Blume & 14 & 7.00 & 0.92 & 0.22 & 2.17 & 0.01 & 0.10 & 3.20 \\
Amorphophallus muelleri Blume & 5 & 2.50 & 0.33 & 0.22 & 2.17 & 0.00 & 0.04 & 2.54 \\
Homalomena pendula (Blume) Bakh.f. & 14 & 7.00 & 0.92 & 0.11 & 1.09 & 0.01 & 0.10 & 2.11 \\
Nephrolepis cordifolia (L.) C. Presl & 25 & 12.50 & 1.65 & 0.11 & 1.09 & 0.02 & 0.18 & 2.92 \\
Pothos scandens L. & 48 & 24.00 & 3.17 & 0.11 & 1.09 & 0.03 & 0.35 & 4.61 \\
Selaginella mittenii Baker & 23 & 11.50 & 1.52 & 0.11 & 1.09 & 0.02 & 0.17 & 2.77 \\
Piper solmsianum C.DC. & 35 & 17.50 & 2.31 & 0.11 & 1.09 & 0.02 & 0.26 & 3.65 \\
Piper lowong Blume & 34 & 17.00 & 2.24 & 0.11 & 1.09 & 0.02 & 0.25 & 3.58 \\
Merremiaum bellata (L.) Hallier f. & 14 & 7.00 & 0.92 & 0.11 & 1.09 & 0.01 & 0.10 & 2.11 \\
Stenochlaena palustris (Burm. f.) Bedd. & 15 & 7.50 & 0.99 & 0.11 & 1.09 & 0.01 & 0.11 & 2.19 \\
Molineria latifolia (Dryand. ex W.T.Aiton) Herb. & 12 & 6.00 & 0.79 & 0.11 & 1.09 & 0.01 & 0.09 & 1.97 \\
ex Kurz & & & & & & & \\
Scleria sp. & 11 & 5.50 & 0.73 & 0.11 & 1.09 & 0.01 & 0.08 & 1.89 \\
Thyrsostachys siamensis Gamble & 5 & 2.50 & 0.33 & 0.11 & 1.09 & 0.00 & 0.04 & 1.45 \\
Freycinetia banksii A.Cunn. & 3 & 1.50 & 0.20 & 0.11 & 1.09 & 0.00 & 0.02 & 1.31 \\
Cyclanthera cordifolia & 4 & 2.00 & 0.26 & 0.11 & 1.09 & 0.00 & 0.03 & 1.38 \\
Schefflera elliptica (Blume) Harms & 8 & 4.00 & 0.53 & 0.11 & 1.09 & 0.01 & 0.06 & 1.67 \\
Cissus javana DC. & 14 & 7.00 & 0.92 & 0.11 & 1.09 & 0.01 & 0.10 & 2.11 \\
Amorphophallus bulbifer (Roxb.) Blume & 15 & 7.50 & 0.99 & 0.11 & 1.09 & 0.01 & 0.11 & 2.19 \\
\hline
\end{tabular}

Table 5. Plant diversity index in all vegetation stages represented using Shannon Diversity Index $(\mathrm{H})$

\begin{tabular}{lll}
\hline Vegetation stage & Diversity Index $(\mathbf{H})$ & Category \\
\hline Tree & 2.59 & Moderate \\
Saplings & 2.76 & Moderate \\
Understorey plants (shrubs and herbs) & 4.01 & High \\
\hline
\end{tabular}

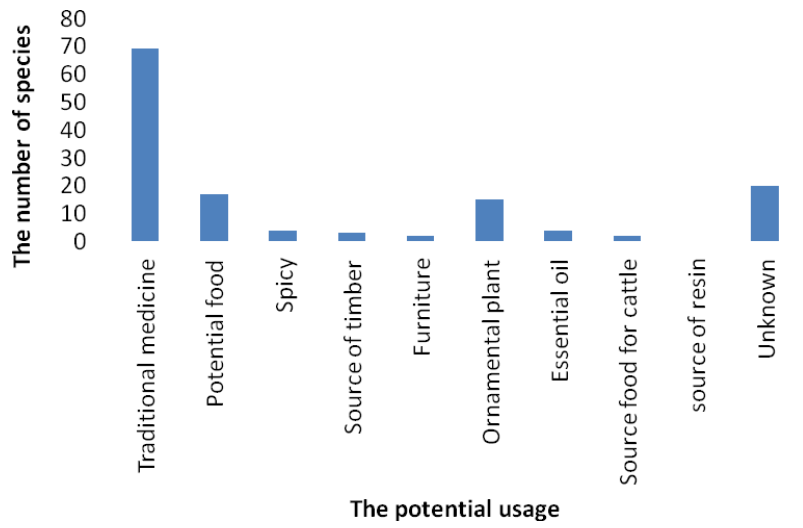

Figure 5. The potential use of plant diversities in Karangsambung-Karangbolong National Geopark. The plants are grouped based on their usages. The information was gathered from the literature review

In Karangsambung-Karangbolong National Geopark, plant richness at the mountainous location tends to have a higher value. The highest species richness was recorded in location 10 (Watukelir), followed by location 6 and location 11 (Pager Jawa). Those locations have a steep hill topography that is far away from human activities. Several locations at higher elevation tend to have a higher plant richness because of few human activities there. The vegetation at higher elevation is still relatively dense and diverse even though some areas are converted into plantation. This is understandable because the lowland areas in the Geopark are mostly converted into agriculture, plantation, and settlement, making the richness of species is relatively low. Pager Jawa (location 11) is considered as a location with high plant richness which is dominated by palms and woody trees. The results of this study are not in accordance with Rahbek (1995) that stated the diversity tends to decrease with increasing elevation, but this is applied to pristine or primary forest.

Plants having a high value of Important Value Index (IVI) indicates that those plants are dominant in the region, have better adaptability and play the most important role than others. According to Lubis (2009) and Abdiyani (2008), a type of vegetation can affect the stability of an ecosystem because it is dominant in terms of environmental changes and vegetation competition. The result of calculation of Important Value Index (IVI), Ficus scortechinii King, Litsearu biginosa Boerl., Ardisias anguinolenta Blume have the highest IVI for tree vegetation stage with the value $>17$. For sapling vegetation stage, Leea indica (Burm. f.) Merr., Litsea plateaefolia Elmer, and Lepis anthesalata (Blume) Leenh have the highest IVI with value $>30$. For groundcover, Melastoma malabathricum L, Clidemia hirta (L.) D. Don, Zingiber zerumbet (L.) Roscoe ex Sm., Cyclosorus opulentus (Kaulf.) Nakaike, Dicranopteris linearis (Burm. f.) Underw., Ageratum conyzoides (L.) L. are plants that having IVI $>5$. 
Melastoma malabathricum is considered a native plant of tropical Asia, subtropics and the Pacific Islands. This plant is generally found in bushes, rice fields, and mountain slopes. The plant itself belongs to Melastomataceae family which is generally in the form of shrubs, shrubs or trees. The population grows wild on open or protected land, on dry or moist soil, lowland to an altitude of $2000 \mathrm{~m}$ above sea level. This plant is a weed on perennial plantation, such as rubber, coconut, oil palm and teak (Joffry et al. 2012). Clidemia hirta is originated from South America, blooms throughout the year, spreads very quickly and is relatively more abundant outside its native area than its natural habitat. C. hirta is a type of understorey plant which has high adaptability because it is able to grow optimally at low altitudes up to $1000 \mathrm{~m}$ above sea level with open and humid environmental conditions and soil that has a high humus content (Ismaini 2015). Ageratum conyzoides is native to Tropical America, especially Brazil, and considered as an invasive weed in many other regions including in Africa, Australia, Southeast Asia, and the USA. A. conyzoides is relatively well adapted in any kind of environmental condition (Weakley 2008). Zingiber zerumbet has a high IVI because this plant is planted by local people and dispersed very quickly in most regions in this geopark.

Based on Shannon Diversity Index $(\mathrm{H})$, the diversity of tree and saplings vegetation are relatively moderate in Karangsambung-Karangbolong National Geopark with a score of 2.59 and 2.76, respectively. Miardini et al. (2010) state that $\mathrm{H}$ value of $1 \leq \mathrm{H} \leq 3$ shows that the diversity of species in an area is moderate, the distribution of the number of individuals per species is moderate and the stability of the community is moderate. Meanwhile, the diversity of understorey plants is relatively high with a score of 4.01. High or low value of the diversity index is influenced by the number of species and the number of individuals found. According to Samingan (1976) the more species found, the higher the Diversity Index value. The higher the Diversity Index value of an area shows the more stable the community in the region. The vegetation in Karangsambung-Karangbolong is dominated by shrub and herbs with only few trees and sapling. The landscape of Karangsambung-Karangbolong is mostly dominated by understorey plants (shrubs and herbs) because most of areas have been converted into forest plantation with homogenous tree species composition. Many shrubs and herbs that found in the area have potential benefits as herbal medicine, some of them have different uses such as potential food, spice, ornamental plant, essential oil, and many others.

In conclusion, the highest species richness of plants in Karangsambung-Karangbolong National Geopark is found at the locations with the mountainous topography (steep hills). Watu Kelir and Pager Jawa are two locations that still have high diversity of plants compared to the other locations. The understorey plants (shrubs and herbs) dominated the landscape of Karangsambung-Karangbolong National Geopark. Melastoma malabathricum, Clidemia hirta, Ageratum conyzoides, and Zingiber zerumbet are the most abundant species in all sampling locations. Most of plants in this area have potential uses as herbal medicine.

\section{ACKNOWLEDGEMENTS}

We are highly appreciated and thankful to Indonesian Institute of Sciences (LIPI) for giving research funds to our team. We also thank to Bapak Ikar Supriyatna who helping to identify the plant species. A lot of thanks delivered to Bapak Haris who help us to collect data during fieldwork.

\section{REFERENCES}

Abdiyani S. 2008. Keanekaragaman jenis tumbuhan bawah berkhasiat obat di Dataran Tinggi Dieng. Jurnal Penelitian Hutan dan Konservasi Alam 1 (5): 79-92. [Indonesian]

Asikin S. 1974. Evolusi Geologi Jawa Tengah dan Sekitarnya Ditinjau dari Segi Teori Tektonik Dunia yang Baru. [Disertasi]. Departemen Teknik Geologi ITB, Bandung. [Indonesian]

Colwell RK, Hurtt GC. 1994. Non-biological gradients in species richness and a spurious Rapoport effect. Am Nat 144: 570-595.

Colwell RK, Lees DC. 2000. The mid-domain effect: geometric constraints on the geography of species richness. Trends Ecol Evol 15: $70-76$

Curtis JT, McIntosh RP. 1950. The interrelations of certain analytic and synthetic phytosociological characters. Ecology 31: 434-455.

Curtis JT. 1959. The vegetation of Wisconsin. An ordination of plant communities. University of Wisconsin Press, Madison, WI.

Ismaini L. 2015. Pengaruh alelopati tumbuhan invasif (Clidemiahirta) terhadap germinasi biji tumbuhan asli (Impatiens platypetala). Prosiding Seminar Nasional Masyarakat Biodiversitas Indonesia 1 (4): 834-837. [Indonesian]

Joffry SM, Yob NJ, Rofiee MS. 2012. Melastoma malabathricum (L.) smith ethnomedicinal uses, chemical constituents and pharmacological properties: a Review. Evid-Based Compl Altern Med. 2012: 258434. DOI: 10.1155/2012/258434

Lomolino VM. 2001. Elevation gradients of species-density: historical and prospective views. Glob Ecol Biogeogr 10: 3-13.

Lubis SR. 2009. Keanekaragaman dan pola distribusi tumbuhan paku di Hutan Wisata Alam Taman Eden Kabupaten Toba Samosir Provinsi Sumatera Utara. Pascasarjana Universitas Sumatera Utara, Medan. [Indonesian]

MacArthur RH. 1972. Geographical Ecology. Harper \& Row, New York.

Miardini A, Boediyono A, Atmoko BD, Harjadi B, Gunawan. 2010. Analisis kerentanan tumbuhan hutan akibat perubahan iklim. Badan Penelitian dan Pengembangan Hutan, Surakarta. [Indonesian]

Pausas JG, Austin MP. 2001. Patterns of plant species richness in relation to different environments: an appraisal. J Veg Sci 12: 153-166.

Raharjo PD, Ansori C. 2009. Kajian Penggunaan Lahan Pada Kawasan Cagar Alam Geologi Karangsambung dengan Menggunakan Sistem Informasi Geografis. International Conference Earth Science and Technology, Yogyakarta 6-7 August 2009. [Indonesian]

Raharjo PD, Hidayat E, Widiyanto K, Puswanto E, Winduhutomo S, Triharjito A, Purwantoro, Purnami DN. 2011. Sistem Informasi Sumberdaya Lahan dan Air Cagar Alam Geologi Karangsambung. Laporan Teknis. Kegiatan Penelitian dan Pengembangan Ilmu Pengetahuan dan Teknologi, LIPI, Kebumen. [Indonesian]

Rahbek C. 1995. The elevational gradient of species richness: a uniform pattern? Ecography 18: 200-205.

Rahbek C.1997. The relationship among area, elevation, and regional species richness in Neotropical birds. Am Nat 149, 875-902.

Samingan T. 1976. Pemantaran metode pendugaan hasil potensi hutan dalam rangka kelestarian pemungutan hasil hutan. Buletin PERSAKI 8 (1): 3-9. [Indonesian]

Vetaas OR, Grytnes JA. 2002. Distribution of vascular plants species richness and endemic richness along the Himalayan elevation gradient in Nepal. Glob Ecol Biogeogr 11: 291-301.

Weakley AS. 2008. "Flora of the Carolinas, Virginia, and Georgia, and Surrounding Areas". University of North Carolina at Chapel Hill, Chapel Hill, NC. http://www.herbarium.unc.edu/flora.htm. 